\title{
Diminuarea dificultāțillor de predare-învāțare în sistemul on-line
}

\section{Oana PREDA ${ }^{1}$}

\begin{abstract}
The COVID-19 pandemic that resulted in a shift towards on-line teaching and learning resulted in countless difficulties concerning the access to efficient education, especially in the case of children from families with a lesser-endowed socio-economic and cultural background, or children with learning problems, with ADHD or various disabilities (visual or healing impairment, intellectual disabilities, autism spectrum disorders, etc.). Moreover, even pupils who actually have technical access to the new teaching-learning system run the risk of losing their motivation for learning.

The efficient activity of and the results obtained by many teachers whose approach has been successful have shown the efficiency of integrated curricula whose teaching tasks are structured in learning sequences and whose testing patterns are personalized. By putting into practice, the principle of cognitive motivation development through an interactive process of teaching and learning that relies on structured learning sequences and employs personalized assessment techniques, reaching formative pedagogical objectives becomes possible even in the on-line teaching-learning system.
\end{abstract}

Keywords: online teaching system, online learning, motivation for learning, interactive process, structured learning sequences, personalised assessment.

Pandemia cauzată de COVID-19 a dus la trecerea în sistemul de predare-învățare on-line, ceea ce a creat numeroase dificultăți de acces la o reală educație mai ales pentru copiii proveniți din familii cu un statut socio-economic şi cultural scăzut. Mulți elevi din mediul rural sau din oraşe care nu dispun de tablete, computere sau o infrastructură de acces la internet adecvată sunt, de fapt, excluși din sistemul de predare-învățare on-line.

Problemele dificil de surmontat create de sistemul on-line sunt mai mari la elevii cu dificultăți de învățare, cu ADHD şi la cei cu diferite dizabilități (de auz, de vedere, intelectuale, tulburări din spectrul autist etc.).

Pe fondul sistemului de predare on-line există riscul scăderii pronunțate a motivației învățării, chiar şi la elevii care din punct de vedere tehnic au acces la acest sistem instructiv-educativ on-line.
Tocmai de aceea se impune ca profesorii și părinții elevilor să prevină în primul rând scăderea motivației învătării. Stimularea motivației este o premisă importantă pentru participarea conștientă şi activă a elevilor la învățarea on-line.

1. Rolul obiectivelor din domeniul afectiv, motivaţional şi cognitiv în predarea online

Pentru integrarea şcolară a copiilor şi tinerilor in sistemul on-line este necesar să se asigure o convergenţă a numeroşi factori: socio-economici şi culturali familiali, infrastructură a şcolilor, climat educaţional, strategii psihopedagogice şi psihologice de incluziune școlară, stimularea motivaţiei pentru învățare, aplicarea teoriei inteligențelor multiple, curriculum adaptat, strategii didactice activizante şi evaluare formativă. 
Lipsa sau insuficienta motivaţie pentru învăţarea şcolară poate să fie determinată de atitudinea indiferentă sau chiar ostilă pentru actul educaţional şcolar în sistemul on-line, manifestată de unii părinţi care au o situaţie economică şi culturală precară şi care neglijează dezvoltarea personalităţii copiilor. În astfel de cazuri, pe langă măsurile economico-sociale luate pe baza politicii de combatere a sărăciei, se impune o intervenţie educativă timpurie pentru copiii proveniţi din familii defavorizate, prin implicarea mediatorului şcolar şi a profesorilor de sprijin pentru consilierea părinţilor şi elevilor.

Programele de „Educație remedială” şi de stimulare cognitivă care trebuie concepute personalizat în sistemul de predareînvățare on-line sunt utile pentru prevenirea şi combaterea abandonului şcolar. Dar se știe că inteligența este pusă în funcţie şi orientată spre anumite scopuri de factorii emotiv-activi ai personalităţii şi că în structura aptitudinii şcolare alături de factorii intelectuali fiinţează şi factori nonintelectuali, în rândul cărora cei motivaţionali şi afectivi deţin o pondere însemnată.

Desigur, motivaţia intrinsecă a învăţării se formează mai greu şi nu la toţi elevii, dar emoțiile legate de cunoaştere şi diverse trebuinţe pot fi stimulate şi dezvoltate la niveluri care să permită valorificarea potenţialului cognitiv real al elevilor. Transpunerea în fapt a principiului învăţării prin acţiune şi a principiului stimulării şi dezvoltării motivaţiei cognitive facilitează atingerea unor obiective didactice formative (Preda, 2009 a, p. 111-140).

İn strânsă interrelaţie cu crearea optimum-ului motivaţional în condițiile predării on-line, fiecare profesor va urmări dezvoltarea unor stări afective stenice, care să reducă anxietatea unora dintre elevi, iar pe fondul echilibrului afectiv să se clădească atracția faţă de conținutul disciplinei şcolare predate. Pornind de aici, pe baza strategiilor didactice activizante, a unor tehnici motivogene, se poate dezvolta plăcerea de a învăța, curiozitatea, încrederea în capacităţile cognitive, bucuria succesului, bucuria descoperirii/redescoperirii soluţiilor unor probleme, a unor reguli, principii etc.

Substructurile psihice afective şi motivaţionale necesare învățării sunt atât premise, cât şi consecințe ale atingerii obiectivelor cognitive, concepute în desfăşurarea lor procesuală, inclusiv a celor operaţionalizate. Pentru atingerea obiectivelor formative este necesar ca profesorul să stimuleze emoţiile şi sentimentele cognitive ale elevilor, inclusiv prin adaptarea curriculară pentru sistemul on-line şi aplicarea unor programe de învățare remedială.

\section{Stimularea motivației învățării in contextul predării on-line}

Predarea în sistemul on-line impune remodelări ale predării-învațării şi ale programului de evaluare, precum şi întăriri pozitive în consens cu particularităţile psihosociale ale elevilor şi cu cerinţele curriculare. În aceste condiţii, măiestria pedagogică îşi spune cuvântul, profesorul bun fiind capabil de a stârni curiozitatea elevilor prin „elemente-surpriză” incluse în demersul didactic (filme, imagini, scheme relevante pentru tema care s-a abordat).

Instruirea interactivă în sistem on-line face posibilă organizarea unor activităţi în 
care se întrepătrund caracteristicile programelor educaţionale cu reprezentările, cunoştinţele empirice, dorinţele şi preocupările elevilor. În actuala paradigmă a design-ului educațional in sistemul on-line, activitatea de predare-învăţare trebuie sa fie axată pe achiziţia unor competenţe tot mai complexe şi variate: cognitive, afectivmotivaţionale şi nu doar pe asimilarea unor informaţii.

Mai mulţi cercetători (Ausubel, Robinson, 1981; Wigfield, Eccles şi Rodriguers, 1998, p. 73-108; Laveault, Leblanc şi Lerou, 1999, p. 81- 98) au subliniat faptul că sporirea eficienței procesului de predare-învăţare şi a autoreglării învăţării şcolare se poate realiza pe baza interacţiunii între procesele cognitive, metacognitive şi determinanţii moţivaţionali. În acest sens, este util să se ia în considerare următoarele aspecte psihopedagogice care contribuie la dezvoltarea motivaţiei şcolare menționate de mai mulți cercetători (Ausubel, Robinson, 1981; Preda 2009 b, p.137-140) :

Acceptarea unui punct de vedere realist privind aspectele reale ale funcţionalităţii motivaţiei elevilor. Profesorii trebuie să accepte că motivaţia extrinsecă şi motivația intrinsecă pot duce - prin întrepătrunderea lor - la creşterea randamentului şcolar.

Evaluarea motivelor învăţării. În cazul în care unui elev nu i se poate capta atenţia şi interesul, profesorul trebuie să detecteze şi să evalueze exact structura şi funcţionalitatea sistemului motivaţional, emoţiilor şi sentimentelor cognitive ale elevului respectiv, raportându-le la cerințele sarcinilor didactice.
Dezvoltarea impulsului cognitiv, pe baza stimulării şi orientării trebuinței de activism şi a trebuinţei de explorare, paralel cu stimularea şi dezvoltarea emoţiilor şi sentimentelor cognitive (curiozitatea, mirarea, îndoiala, bucuria descoperirii).

Punerea în funcţiune a unui nivel adecvat al motivaţiei. Cercetările au demonstrat că forţa mobilizatoare şi eficienţa optimumului motivațional sunt determinate de trebuinţa de performanţă şi nivelul de aspiraţie al elevului, de capacitatea sa de autocunoaştere şi de evaluarea adecvată a dificultăţilor reale ale sarcinilor didactice. Motivaţia optimă scurtează timpul necesar învăţării, inclusiv la elevii cu ritm mai lent, la care prin activizarea proceselor cognitive se antrenează şi ritmul învățării.

Utilizarea predarii pe grupe de nivel. Elevul poate fi determinat să intre în „competiţie” cu propriile sale realizări anterioare.

\section{strategif ulidactice favoralille prenărit- învătărifi in sistemul on-lïne}

Bunele practici ale profesorilor au demonstrat că în sistemul de predare online sarcinile didactice care sunt structurate pe secvențe de învățare şi pe utilizarea unor teste de cunoştințe lasă libertatea alegerii de către elevi a unor itemi suplimentari, gradual mai complecşi, pe lângă itemii obligatorii. În aceste condiţii se antrenează şi se dezvoltă trebuinţa de performanță şi nivelul de aspiraţie al elevilor.

În sistemul predării-învățării în sitemul on-line, programele curriculare integrate şi proiectele educative personalizate pot viza competențele care trebuie urmărite 
cu precădere pentru fiecare copil, vizând zona proximei dezvoltări a substructurilor cognitive, pe un fond motivaţional-afectiv stenic.
Conținuturile disciplinelor, strategiile didactice şi programele personalizate de intervenție educativă în sistemul on-line trebuie structurate pe secvenţe de învăţare (Tabelul 1).

Tabelul 1.Avantaje ale utilizării unui program structurat pe secvențe de învățare

\section{Asigurarea unui mediu stimulativ}

\begin{tabular}{ll}
\hline Avantaje pentru elev & Avantaje pentru profesor \\
\hline suscită interesul; & prezintă informaţia în mod atractiv, corespunzător \\
incită la experimentare în variante diferite; & nivelului de pregătire al copilului; \\
$\begin{array}{l}\text { activitatea de învătare se poate desfășura şi pe } \\
\text { baza jocurilor didactice, a unor filme, imagini } \\
\text { relevante. }\end{array}$ & mobilizarea adecvată previne activismul redus al \\
unor elevi.
\end{tabular}

Creșterea graduală a dificultății secvențelor de învățare

\begin{tabular}{l}
\hline Avantaje pentru elev \\
repetă secvența în variante modificate până la \\
însuşirea completă a informației; \\
revine la secvențele anterioare, permițând reluarea \\
traseului percepţie $\rightarrow$ reprezentare $\rightarrow$ noțiune; \\
permite utilizarea transpunerii în cuvinte și a \\
utilizării unor simboluri care mediază \\
interiorizarea acțiunilor obiectuale.
\end{tabular}

Avantaje pentru profesor

recurge la activităţi adecvate particularităților

individuale, respectând ritmul de lucru al

copilului;

sesizează mai rapid ceea ce nu a înțeles copilul și

revine la secvențe mai uşoare sau în variante mai simple

acţiunea efectivă însoţită de verbalizare duce la consolidarea conţinutului obiectual în variante de joc și învăţare.

Restructurarea şi transferul informaţiilor se realizează mult mai uşor şi mai rapid

Avantaje pentru elev Avantaje pentru profesor

este solicitat să caute rezolvări în situaţii variate; reţine mai uşor elementele esenţiale şi poate recurge la generalizări;

este stimulat să recurgă la raţionamente.

mobilizează adecvat capacitatea de memorare şi transfer de cunoștințe;

solicită anticiparea şi apelul la situaţii virtuale pe bază de raţionamente.

\begin{tabular}{ll}
\hline Suportul afectiv şi motivaţional adecvat & \\
\hline Avantaje pentru elev & Avantaje pentru profesor \\
\hline trăieşte succesul şi se simte provocat pentru a & evaluarea mai uşoară a gradului de stăpânire a \\
accepta sarcini mai dificile; & noţiunilor/cunoștințelor; \\
revenirea la o secvenţă anterioară găsind un feed- & mobilizează mai intens potenţialul de învăţare al \\
back adecvat în situațiile în care soluţiile nu pot fi & $\begin{array}{l}\text { copilului; } \\
\text { permite deprinderea copilului cu autoevaluarea } \\
\text { contestate ori puse la îndoială. }\end{array}$ \\
& cunoștințelor . \\
\hline
\end{tabular}

Pentru construirea instrumentelor de gândire, cercetătorii (Tardif,1970; Perraudeau, 1996) consideră că în proiectarea demersului de predare centrat pe stimularea cognitivă trebuie să se țină seama de următoarele cerințe:
- proiectarea strategică a sarcinilor şi informaţiilor de învățat, ceea ce implică atenţia, anticiparea şi verificarea din partea elevului, iar din partea profesorului este necesară specificarea 
tipului de ghidaj şi a modului de derulare a lecţiilor prin secvenţe de învăţare structurate logic;

- asigurarea unei autoreglări cognitive cu centrare pe sarcină;

- materialul de învățat prezentat elevului trebuie să faciliteze centrarea pe sarcină şi nu pe date irelevante;

- să fie încurajată autoevaluarea;

- să existe o fază de transfer între sarcina efectuată şi alte sarcini şcolare.

- evaluarea cunoştințelor să fie predominant formativă.

În sistemul de predare on-line, este util ca profesorii să țină seama de ideile lui Bruner (1970, p. 41), care arată că prin activizarea elevului, procesul de instruire asigură participarea sa conştientă la asimilarea cunoștințelor şi utilizarea acestora în diferite contexte: „A instrui pe cineva nu este o chestiune de înmagazinare de rezultate (memorare de informaţii), ci presupune a-l învăţa să participe la procesul care face posibilă crearea de cunoştinţe; nu predăm o materie oarecare pentru a produce mici biblioteci vii în acea materie, ci pentru a-l face pe elev să gândească el însuşi şi să ia parte la procesul de creare a cunoştinţelor. Cunoașterea este un proces, nu un produs."

$\mathrm{O}$ consecinţă ce rezultă din teoria lui Bruner se referă la faptul că pentru eșecul şcolar al unor elevi, pe lângă lipsa interesului și motivației școlare, există cel puţin două explicaţii de nuanţă pedagogică:

a) Disciplinele pe care trebuie să le parcurgă elevii nu sunt predate într-o manieră care să satisfacă modalitatea de reprezentare a lumii şi de cunoaştere specifică fiecărui elev (activă-obiectuală, iconică, simbolică)

b) În proiectarea şi implementarea procesului de instruire se ignoră dimensiunea culturală a învăţării (există probleme şi modalități de soluţionare a acestora tipice unei culturi sau alteia). Prin urmare, recomandarea lui Bruner este ca predarea unei discipline să se facă astfel încât să se pornească de la modalitatea de gândire prin care operează copilul.

Procesul de învăţământ, prin modul de structurare a informaţiei, trebuie să evidenţieze şi să dezvolte operaţiile cognitive cerute de situațiile-problemă, iar activitatea cognitivă trebuie analizată în conformitate cu strategia sau regulile $\mathrm{cu}$ ajutorul cărora informaţia este organizată, transformată, manipulată şi reprezentată mintal pentru a da naştere la o informaţie nouă. Se desprinde de aici ideea cu privire la structurarea curriculum-ului în spirală: învăţarea şi apoi reluarea unor concepte, principii și strategii rezolutive $\mathrm{cu}$ o mai mare complexitate la nivelurile şcolare superioare.

\section{Bibliografie}

Ausubel, P.D., Robinson, G.F. (1981). Învăţarea în şcoală. O introducere în psihologia pedagogică. București E.D.P.

Bruner, J. (1970).Pentru o teoriea instruirii.București: E.D.P.

Laveault, D., Leblanc, R., Leroux, J. (1999). Autorégulation de l'apprentisage scolaire: interaction entre processus métacognitifs et déterminants de la motivation. În: C. Depover, B. Noël (Eds.) L'évaluation des compétences et 
des processus cognitifs. Paris, Bruxelles: De Boeck \&Larcier: p. 81- 98.

Perraudeau, M. (1996). Les méthodes cognitives. Apprendre autrement à l'école. Paris: Armamd Colin.

Preda, V. (2009 a). Principiile didacticii în viziunea teoriilor constructiviste. In : M. Ionescu, M. Bocoş (coord.).Tratat de didactică modernă.Pitești, Editura Paralela 45 : 111-144.

Preda, V. (2009 b). Obiectivele procesului de predare-învăţare.In : M. Ionescu, M. Bocoş (coord.).Tratat de didactică modernă.Pitești, Editura Paralela 45 : 145-170.
Tardif, J. (1997). Pour un enseignement stratégique. L'apport de la psychologie cognitive. Montréal: Les Editions Logiques.

Wigfield, A., Eccles, J.S., Rodriguers, D. (1998). The development of children's motivation in school contexts. Review of Research in Education, 23: 73-118.

1. Profesor psihopedagog. Şcoala Gimnazială Specială CRDEII Cluj-Napoca

Email: oana preda2004@yahoo.com 